\title{
Experimental Investigation of the Mechanical and Microstructure Properties of S49 Rail Steel
}

\author{
Anıl Rıdvanoğulları ${ }^{1 *} \mathbb{D}$, Tayfun Çetin $^{2} \mathbb{D}$ and Mehmet Akkaş ${ }^{3} \mathbb{D}$ \\ ${ }^{1 *}$ Muş Alparslan University, Department of Motor Vehicles and Transport Technologies, 49250, Güzeltepe, Muş, Turkey. (e-mail: \\ a.ridvanogullari@alparslan.edu.tr). \\ ${ }^{2}$ Hakkari University, Department of Electricity and Energy, 30000, Hakkari, Turkey. (e-mail: tayfuncetin@ hakkari.edu.tr). \\ ${ }^{3}$ Kastamonu University, Department of Mechanical Engineering, 37150, Kastamonu, Turkey. (e-mail: \\ mehmetakkas@kastamonu.edu.tr).
}

\section{ARTICLE INFO}

Received: Oct., 18. 2020

Revised: May., 19. 2021

Accepted: Jun, 20. 2021

Keywords:

S49 rail steel

Mechanical properties

Three-point bending

Microstructure

Hardness

Corresponding author: Anıl

Rıdvanoğullart

ISSN: $2536-5010$ | e-ISSN: 2536-5134

\section{ABSTRACT}

This study was carried out to determine the microstructure and mechanical properties of S49 rail steel. For this purpose, firstly, three samples of S49 rail steel material were prepared by cutting by wire erosion method for three-point bending test. Microstructural analyses of S49 rail steel were examined by scanning electron microscopy (SEM). Energy dispersion spectrometer (EDS) analysis was performed to determine the chemical composition of the S49 rail steel material. Hardness test and three-point bending test were performed to determine the mechanical properties of the samples. SEM and EDS analyses of fractured surfaces were performed from the broken samples after the three point bending test.

DOI: https://doi.org/10.17694/ejt.812142

\section{INTRODUCTION}

Railway transport has an important place in both freight and passenger transport. Railway transportation, which is in the safe class in the field of logistics, consists of three main parameters as railway, vehicles and facilities [1]. Railway is divided into two main components as infrastructure and superstructure. Railway infrastructure is known as all kinds of excavation work (ground consolidation) to be able to build a superstructure on the railway whose route is determined. The superstructure, on the other hand, is the part consisting of rails, sleepers, ballasts and fasteners that enable the movement of railway vehicles and transfer the loads on them to the platform [2-4].

The rail, which is one of the elements that make up the railway superstructure, is a very important element for the superstructure that enables the railway vehicles to roll (move) on it and is responsible for transferring the weight and forces from the vehicles to the ballast and sleeper. The rail is specially manufactured because it must be resistant to weight and other forces from railway vehicles. A standard rail; It consists of three parts: cork, body and base (Figure 1) [5].

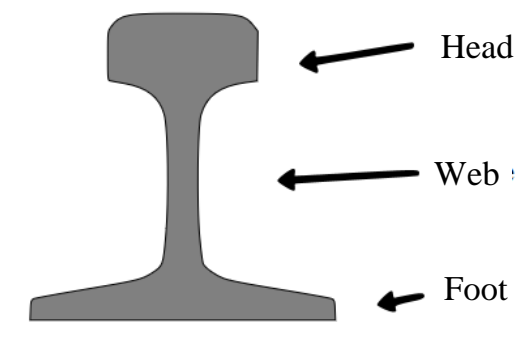

Figure 1. Sections of a standard rail

Rails are divided into classes in terms of shape and weight. S49 (49E1), UIC60 (60E1), which are divided into corrugated, single mushroom, double mushroom. such as the rail's weight per kilogram per meter (Figure 2). 


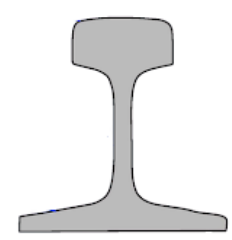

Flat Bottom Rail

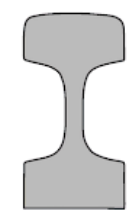

Bull Headed Rail

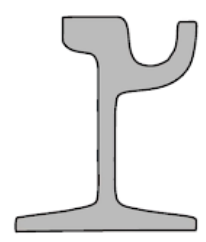

Tram Rail
Figure 2. Rail shapes

Rails should be rigid enough not to wear but flexible enough not to break [6]. As the train speed increases, security problems occur. Therefore, material properties and shape are important in the railway line [7].

S49 (49E1) type rails, which are known to be approximately $49 \mathrm{~kg}$ per meter, are an important type of rail used in rail superstructure for both freight and passenger transportation. It is especially preferred in conventional railway lines. Since conventional lines generally operate under intense operation, the rails are broken, cracked, deteriorated over time. such defects occur.

Due to fatigue damage, which is one of the most common damage to the rails, increase in train operating speeds, higher axle loads and higher traffic density, train logistics will continue and will continue to be important. The contact pressure between the wheel and the rail, which can increase up to $1 \mathrm{GPa}$, and the surface shear stresses that can reach $\mathrm{MPa}$ at high levels can cause plastic deformations in the rails [8]. The surface, microstructural and mechanical properties of the rail have a significant effect on the mechanism of damage that may occur in the rail material during train operating conditions and on the wear resistance of the rail [9]. High and repetitive loads that occur during service conditions cause micro and macro cracks or rail breaks on the surface where the rail contacts the wheel [9]. When these defects cannot be detected within maintenance intervals, they may cause deray events to occur.

\section{EXPERIMENTAL STUDIES}

Standard metallographic processes were applied to obtain images of the samples with scanning electron microscopy (SEM). These applied metallographic processes were applied as sanding, polishing and etching respectively. Scanning electron microscopy (SEM) analysis was taken from the "FEI QUANTA 250 FEG" brand device in Kastamonu University Central Research Laboratory. Energy dispersion spectrometer (EDS) analyzes were taken from the "FEI QUANTA 250 FEG" brand device in Kastamonu University Central Research Laboratory. Hardness measurements were made to determine the mechanical properties of the samples. Hardness measurements were made by DIGIROCK brand macro hardness tester with Rockwell-C hardness measurement method. Since the strength of the test specimens is not in the shape and size of the tensile test specimen, it was measured by the three-point bending test. The bending tests were carried out with a SCHIMATZU type universal test machine according to the ASTM B 528-83 standard. By making a special apparatus shown in Figure 3, the flexural strength of the samples was measured using the TRAPEZIUMX software.

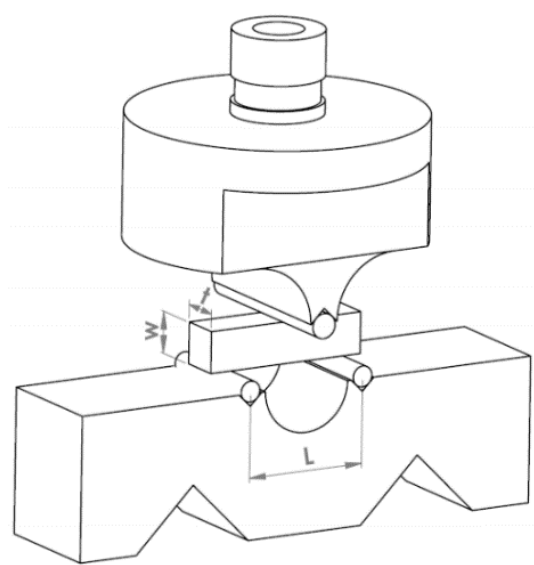

Figure 3. Schematic view of the three-point bending test [10].

In Figure 3, the graphics obtained as a result of the threepoint bending tests for all three sample series are given.

\section{EXPERIMENTAL RESULTS AND DISCUSSION}

SEM image and EDS analysis results taken from S49 rail steel are given in Figure 4.
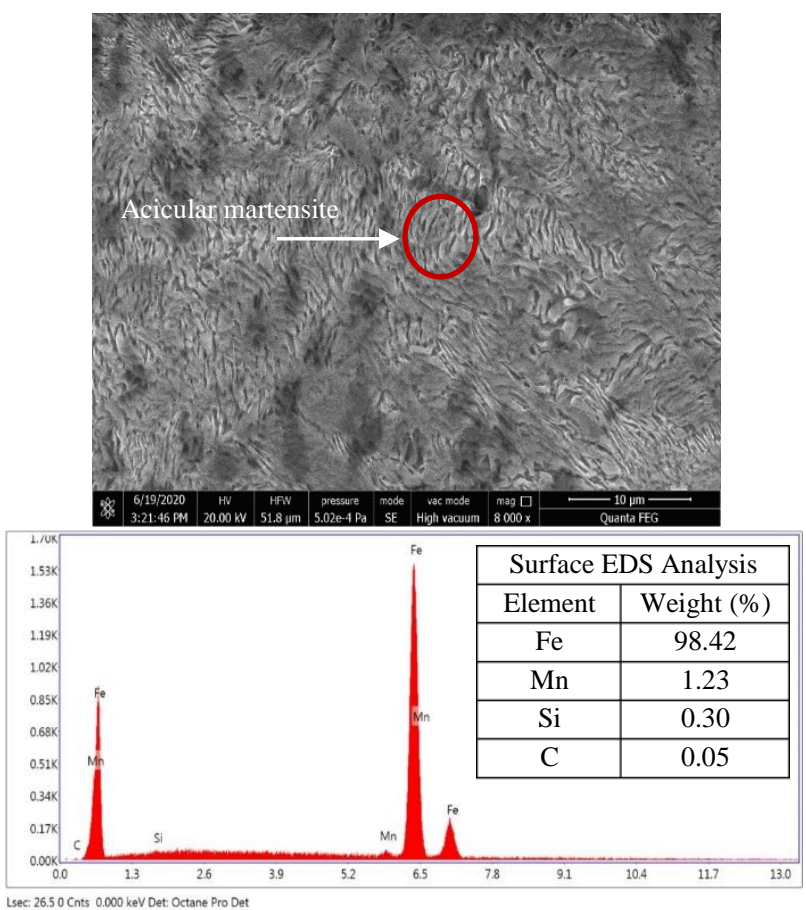

Figure 4. SEM image and EDS analysis of S49 rail steel

When Figure 4 is examined, scattered cementite grains are observed in martensite blocks. In addition, the microstructure is thought to be composed of acicular martensite. When the EDS analysis results given in Figure 4 are examined, it is understood that the material is S49 rail steel material. In addition, when the analysis results are examined, the $\mathrm{Fe}, \mathrm{Mn}$, $\mathrm{Si}$ and $\mathrm{C}$ peaks present in the $\mathrm{S} 49$ rail steel material can be seen clearly $[11,2,12]$. 
TABLE I

HARDNESS VALUES OF S49 RAIL STEEL.

\begin{tabular}{cccc}
\hline 1. & 2. & 3. & Average \\
Measurem & Measure & Measure & Measurement \\
ent & ment & ment & Value \\
\hline
\end{tabular}

\begin{tabular}{ccccc}
\hline HRC & & & & \\
Hardness & 22.2 & 25.4 & 26.7 & 24.76 \\
Value & & & & \\
\hline
\end{tabular}

In order to determine the hardness exactly, hardness values were measured from various parts of the sample and at least five hardness values were taken from all surfaces of each sample. By taking the average of the hardness values measured, the average hardness values of the samples were found (Table 1). Macro hardness measurement values were determined by applying HRC test method and diamond cone tip by applying $10 \mathrm{kgf}$ preload and $150 \mathrm{kgf}$ total load.

In Figure 5, macro images of S49 rail steel after three-point bending are given.

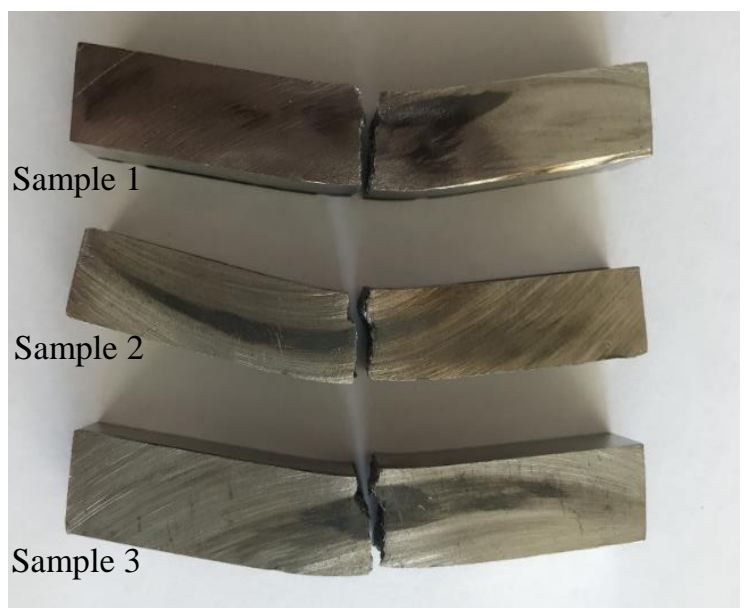

Figure 5. Macro images of S49 rail steel after the three-point bending test

When the sample images given in Figure 5 are examined, it is clearly seen that the samples are broken in the same regions and in the same shapes after the three-point bending test.

Three-point bending strengths of the samples are given in Figure 6 graphically.

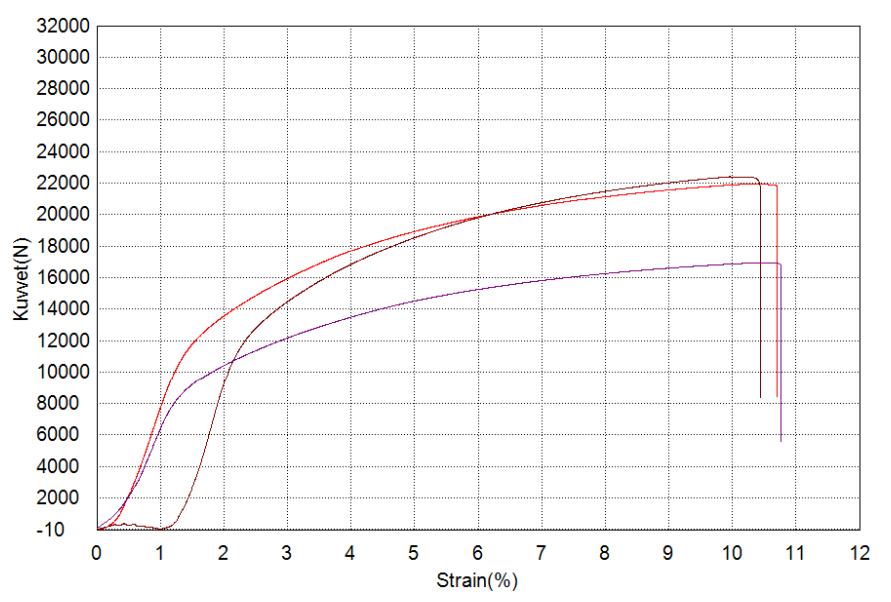

Figure 6. Three-point bending strength graphs of the samples
When the graphic given in Figure 6 is examined, the bending strength of S49 rail steel can be seen clearly. Threepoint bending tests were carried out with three samples. It was measured as $1776 \mathrm{MPa}$ in the first measurement, $2251 \mathrm{MPa}$ in the second measurement and $1301 \mathrm{MPa}$ in the last measurement. The average of three measurements was calculated as $1776 \mathrm{MPa}[8,13]$.

In Figure 7, broken surface SEM and EDS analysis images and results are given after the three-point bending test of S49 rail steel.
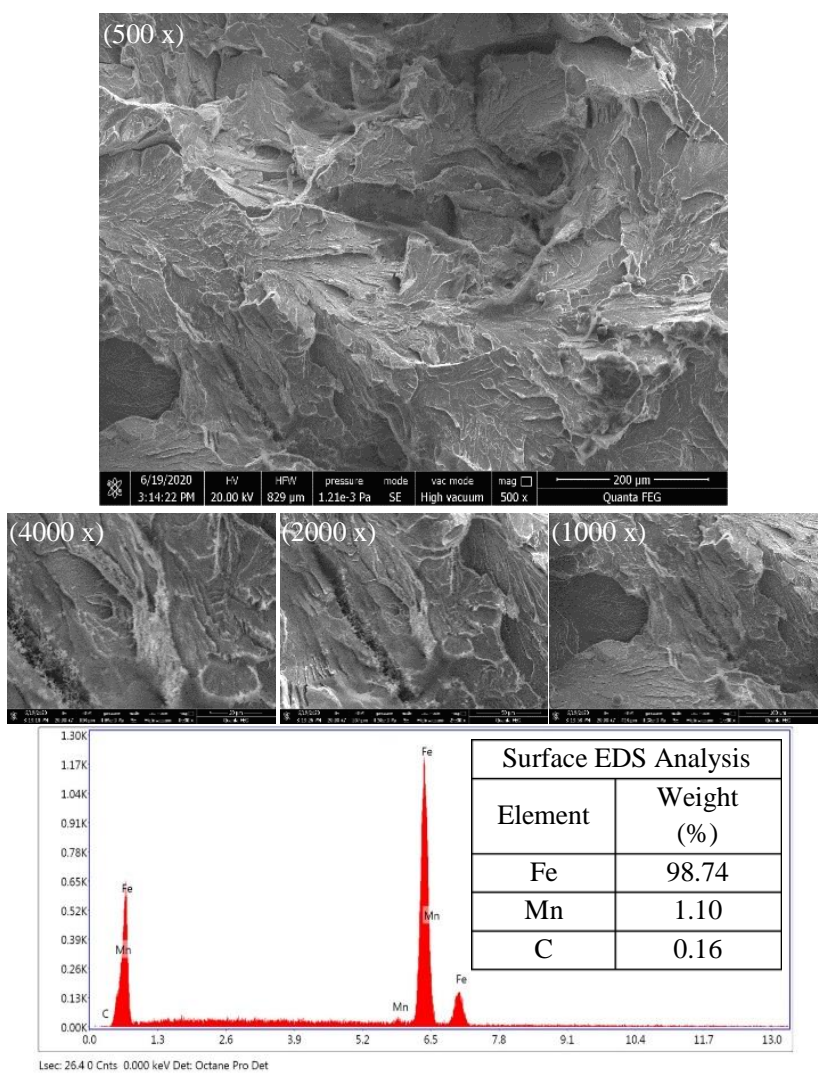

Figure 7. Broken surface SEM and EDS analysis of S49 rail steel after threepoint bending test

When the SEM images given in Figure 7 are examined, it is seen that the S49 rail steel material is broken in a brittle way. Because, when looking at the SEM images of the sample, it is seen that there is too much roughness on the surface and the materials that make up the composition are broken from the grain boundaries. In addition, $\mathrm{Fe}, \mathrm{Mn}$ and $\mathrm{C}$ peaks were detected in the internal structure of the sample as a result of the broken surface EDS analysis [10,14].

\section{CONCLUSION}

In this study, the microstructure and mechanical properties of S49 rail steel were successfully performed. Scanning electron microscopy (SEM), Energy dispersion spectrometer (EDS), hardness, three-point bending test and SEM and EDS analyzes of fractured surfaces were successfully applied to the samples. The report of the experimental results can be summarized as below:

$\mathrm{Fe}, \mathrm{Mn}, \mathrm{Si}$ and $\mathrm{C}$ peaks present in $\mathrm{S} 49$ rail steel material were determined. 
$\checkmark \quad$ In the inner structure, scattered cementite grains were found in martensite blocks.

$\checkmark$ Macro hardness measurement values were measured by HRC test method using a diamond cone tip by applying $10 \mathrm{kgf}$ preload and $150 \mathrm{kgf}$ total load and the hardness value was measured as 24.76 .

$\checkmark$ The average of the three-point bending test measurement was calculated as $1776 \mathrm{MPa}$.

$\checkmark \quad$ It was found that the S49 rail steel material broke brittle after the broken surface.

$\checkmark$ As a result of the broken surface EDS analysis, Fe, $\mathrm{Mn}$ and $\mathrm{C}$ peaks were detected in the internal structure of the sample.

\section{REFERENCES}

[1] Vural, D., Gencer, C. and Karadoğan, D. (2014). Ulaştırma uygulamalarına yönelik çok modlu model önerisi. Savunma Bilimleri Dergisi, 13(1), pp. 75-105.

[2] Kaewunruen, S., Ngamkhanong, C. and Lim, C. H. (2018). Damage and failure modes of railway prestressed concrete sleepers with holes/web openings subject to impact loading conditions. Engineering Structures, 176, pp. 840-848.

[3] Kozak, M. (2011). Demiryolunda Rayların Birleşim Noktaları ve Özelliklerinin Araștırılması. Electronic Journal of Construction Technologies/Yapi Teknolojileri Elektronik Dergisi, 7(2).

[4] Kozak, M. and Ünal, O. (2014). Bazalt Agregası ile Üretilen Beton Travers de Çelik Lifin Kullanılabilirliğinin Araştırılması. Journal of Natural \& Applied Sciences, 18(3).

[5] Özkul, F. (2014). Demiryollarında Ray Birleştirme Yöntemlerinin İncelenmesi, Alüminotermit Ve Yakma Alın Kaynak Yöntemlerinin Karşılaștırılması (Doctoral dissertation, Fen Bilimleri Enstitüsü).

[6] Uzbaş, B. (2013). Demir Yolu İltisak Hatlarında Aşınma Kayıpları. Mühendis ve Makine, cilt 54, say1 638, pp. 39-45.

[7] Eroğlu, M., Esen, İ., Ahlatçı, H., Özçelik, S., Sun, Y. and Pamuk, S (2016). TCDD Karabük-Bolkuş Bölgesindeki 49E1 Raylarda Ondülasyon Ölçümleri Ve Değerlendirilmesi. ISERSE’16, pp. 445451.

[8] Pal, S., Valente, C., Daniel, W. and Farjoo, M. (2012). Metallurgical and physical understanding of rail squat initiation and propagation. Wear, vol. 284-285, pp. 30-42.

[9] Çöl, M., Koç, F.G. and Yamanoğlu, R. (2013). H. Wendel S40 Ray Çeliğinde Yorulma Çatlaklarının Mikroyapısal Karakterizasyonu. ISERSE'13, pp. 251-256.
[10] Çelik E. (2009). Elmaslı kesici takımlarda alternatif bağlayıcılar. Doktora Tezi, F.Ü. Fen Bilimleri Enstitüsü, Elâzı ̆̆.

[11] Cetin, T. and Akkaş, M. (2020). Effect of WC Reinforced on Microstructure and Mechanical Properties of CuAlMn Alloys Produced by Hot Pressing Method. European Journal of Technique, 10(1), pp. 173-183.

[12] Sharma, S., Sangal, S. and Mondal, K. (2016). Wear behaviour of bainitic rail and wheel steels. Materials Science and Technology, 32(4), pp. 266-274.

[13] Merıç, C., Atık, E. Şahın, S. (2002). Mechanical and metallurgical properties of welding zone in rail welded via thermite process. Science and technology of welding and joining, 7(3), pp. 172-176.

[14] Kuziak, R. and Zygmunt, T. (2013). A New Method of Rail Head Hardening of Standard-Gauge Rails for Improved Wear and Damage Resistance. steel research international, 84(1), pp. 13-19.

\section{BIOGRAPHIES}

Anıl Rıdvanoğulları obtained his BSc degree in railway system engineering from Karabük University (KBU) in 2016. He received his MSc from the Mechanical Engineering Department of the same university, Institute of Science, Department of Mechanical Engineering in 2018. Research areas, railway vehicles and equipment. Recently, he focused on rail system superstructure construction and materials. Between 2016 and 2019, he worked as a part-time instructor at Karabük University Railway Systems Engineering. In 2019, he joined Muş Alparslan University Vocational School of Technical Sciences Rail Systems Road Technology program as a lecturer and is still working as a lecturer.

Tayfun Cetin obtained his B.Sc. degree from Firat University in 2010. In 2010, He received his M.Sc. and Ph.D. degrees from Frrat University and Karabuk University in 2014 and 2019 respectively. He started to work as a lecturer at Hakkari University in 2019. He has been workingat Hakkari University since 2019. He works in the fields of powder metallurgy and material science.

Mehmet Akkaș obtained his BSc degree in Metal Teaching Program from Firat University in 2010. He received the MSc. Diploma in Metallurgy Education from Firat University in 2013. He received the Ph.D. diploma in Manufacturing Engineering Department from the Karabük University in 2017. His research interests are powder metallurgy, powder production, gas atomization and composite materials. In 2018 he joined the Department of Mechanical Engineering, Faculty of Engineering and Architecture, Kastamonu University as an assistant professor, where he is presently an assistant professor. 